\title{
Acidification of calf bedding reduces fly development and bacterial abundance
}

\author{
M. S. Calvo, ${ }^{*}$ A. C. Gerry,† J. A. McGarvey, $\ddagger$ T. L. Armitage, ${ }^{*}$ and F. M. Mitloehner ${ }^{* 1}$ \\ *Department of Animal Science, University of California, Davis 95616 \\ †Department of Entomology, University of California, Riverside 92521 \\ ‡USDA Agriculture Research Service, Plant Mycotoxin Research Unit, Albany, CA 94710
}

\section{ABSTRACT}

Environmental stressors, such as high fly density, can affect calf well-being. Sodium bisulfate (SBS) is an acidifier that reduces the $\mathrm{pH}$ of flooring and bedding, creating a medium that neither bacteria nor immature flies (also known as larvae or maggots) can thrive in. Two experiments were conducted to investigate the application of SBS to a mixture of rice hull calf bedding and calf slurry (BED) to reduce house fly (Musca domestica L.) larval density and the abundance of bacteria. In experiment 1 , dish pans containing $1 \mathrm{~L}$ of BED and 3,000 house fly eggs were treated with SBS at concentrations of $0,8.9,17.7$, and $26.5 \mathrm{~g}$ of SBS $/ 0.05 \mathrm{~m}^{2}$ of BED (CON, LOW, MED, and HIGH, respectively), with each SBS concentration applied to 4 individual pans (16 pans total). Reapplication of the same SBS concentrations in each pan occurred 3 times/ wk throughout the 23-d trial. Larval house fly survival was significantly reduced in all pans with SBS relative to CON pans, with lowest survival rates in the MED and HIGH pans (99\% and $100 \%$ reduction, respectively). The mean $\mathrm{pH}$ for each treatment was inversely related to the SBS concentration. In experiment 2, pans containing $1 \mathrm{~L}$ of BED and 3,000 house fly eggs were treated with either $0 \mathrm{~g}$ of SBS (CON), $8.9 \mathrm{~g}$ of SBS/0.05 $\mathrm{m}^{2}$ of BED with reapplication of the acidifier 3 times/ wk $(\mathrm{SB} 3 \times)$, or $8.9 \mathrm{~g}$ of SBS/0.05 $\mathrm{m}^{2}$ of BED applied only once at $48 \mathrm{~h}$ before the end of the $8 \mathrm{~d}$-trial (SB48). Larval house fly survival and bacterial concentrations were reduced (90\% larval reduction and $68 \%$ bacterial reduction) in the $\mathrm{SB} 3 \times$ treatment relative to the $\mathrm{CON}$. Mean $\mathrm{pH}$ was also reduced in SB3 $\times$ pans relative to CON or SB48 pans. Overall, acidification of calf BED using the acidifier SBS resulted in a reduction of bacteria and house fly larval survival. This form of fly control might be expected to reduce adult fly production and, therefore, fly-related stress in calves.

Key words: calf, fly control, acidification, bacteria

Received October 5, 2009.

Accepted November 17, 2009

${ }^{1}$ Corresponding author: fmmitloehner@ucdavis.edu

\section{INTRODUCTION}

Dairy farming provides an environment that supports the growth of house fly larvae (Musca domestica L.; Anderson, 1966; Hansens et al., 1968; Meyer and Petersen, 1983). Manure, silage, grain, and animal bedding are some of the substrates that provide an ideal environment for fly development (Thomsen and Hammer, 1936; Hansens et al., 1968; Meyer and Petersen, 1983). These environments are rich in organic matter and contain bacterial populations suitable as feedstock for developing house flies (Chang and Wang, 1958; Greenberg, 1973; Perotti et al., 2001). Adult house flies can mechanically transmit pathogens that can affect human and animal health (Moriya et al., 1999; Ahmad et al., 2007; Hald et al., 2007). House flies also annoy workers and animals and disperse to nearby urban neighborhoods, creating nuisance conditions (Anderson, 1966; Pickens et al., 1967; Thomas, 1993). On dairies, calf holding pens are often associated with fly production because of the availability of bedding mixed with urine, feces, spilled milk, spilled grain, and water (Schmidtmann, 1988, 1991; Schmidtmann et al., 1989).

The primary means of reducing fly production on animal operations is through sanitation management, which includes the rapid drying of manure through composting or manure separation and harrowing. Additionally, the protection of silage and other organic materials from rain or water runoff will prevent fly development in these substrates (Anderson, 1966; Pickens et al., 1967; Gerry et al., 2007). When sanitation efforts fail (e.g., years with significant summer rainfall), attractant traps and chemical applications can be used for immediate suppression of adult house flies (Gerry et al., 2004). Because fly larvae require bacteria as a food source (Schmidtmann and Martin, 1992; Watson et al., 1993), an antimicrobial product such as sodium bisulfate (SBS) that can be applied to fly development substrates to eliminate or reduce bacterial populations may also prevent larval fly development. A reduction in the bacterial abundance at fly developmental sites may even reduce egg laying at the site by adult flies (Romero et al., 2006). 
Sodium bisulfate is a dry, granular acid that is categorized by the EPA as a mineral acid (EPA, 1993), and has been used as a $\mathrm{pH}$ reducer for many years in agricultural, industrial, and food production. Because of its pH-reducing ability, SBS application creates an inhospitable environment for many species of bacteria. Reduction in bacterial counts from SBS application to bedding or manure in horse, poultry, and dairy facilities has had many effective and documented benefits, including on-farm pathogen reduction, decreased emissions, odor control, and improved animal health and production (Terzich et al., 1998a,b; Pope and Cherry, 2000). However, the larvae-reducing effect of SBS applied to calf bedding has never been evaluated. The present study examined the effectiveness of calf bedding acidification using SBS for reducing immature house fly survival.

\section{MATERIALS AND METHODS}

\section{Insect Colonies}

House flies were obtained from a laboratory colony maintained at the University of California, Riverside. They have been maintained there with larvae fed a standard medium (Mandeville et al., 1988) since their original collection from a dairy in Mira Loma, California, in 1982. Adult flies were held in mesh net cages containing approximately 3,000 mixed-sex flies. After 5 $\mathrm{d}$ of adult development at $27^{\circ} \mathrm{C}$ and $60 \%$ relative humidity, an egg collection cup containing tissue paper soaked with evaporated milk was inserted into 6 separate adult fly cages. After $24 \mathrm{~h}$, the egg collection cups were removed and house fly eggs were separated from the tissue paper by rinsing in deionized water over a United States standard number 100 sieve pan (Thermo Fisher Scientific, Waltham, MA). House fly eggs from all egg cups were washed into a sterile $250-\mathrm{mL}$ beaker, where they were gently mixed in $50 \mathrm{~mL}$ of deionized water. After mixing, $1 \mathrm{~mL}$ of live fly eggs (approximately 3,000 eggs) was removed from the bottom of the beaker using a disposable pipette and placed into separate $1.5-\mathrm{mL}$ microcentrifuge tubes. Microcentrifuge tubes containing eggs in deionized water were immediately placed on wet ice (to prevent hatching) and shipped overnight to the Animal Science Department at the University of California, Davis, where all experimental procedures were conducted.

\section{Testing Arenas}

Testing arenas were plastic or glass dish pans (0.28 $\mathrm{m} \times 0.17 \mathrm{~m} \times 0.1 \mathrm{~m}$ rearing pans) containing $400 \mathrm{~g}$ of rice hull bedding and $600 \mathrm{~g}$ of manure and urine slurry collected from calf housing at the University of California, Davis dairy facility for a total volume of 1 $\mathrm{L}$ of bedding material. The bedding and slurry mixture (BED) was homogenized thoroughly in each pan with a hand-held mixer (Power-Pro 250-Watt, model MX250, Black \& Decker Corporation, Tousson, MD). Approximately 3,000 house fly eggs were added to the surface of the rearing media in each pan, and pans were covered with mesh screen to prevent access by other manure-breeding flies.

\section{Treatment Procedures}

In experiment 1, 4 replicate rearing pans were treated with SBS (Parlor Pal, Jones-Hamilton Co., Walbridge, $\mathrm{OH})$ at concentrations of $0,8.9,17.7$, and $26.5 \mathrm{~g}$ of SBS/0.05 $\mathrm{m}^{2}$ of BED (CON, LOW, MED, and HIGH, respectively). These application rates were used in accordance with our earlier studies (Sun et al., 2008) and are equivalent to $0,1,2$, or $3 \mathrm{lbs}(0,0.45$, 0.91 , and $1.36 \mathrm{~kg}$, respectively) of SBS $/ 5.4 \mathrm{~m}^{2}$ of calf hutch surface area, respectively. The SBS treatment was applied immediately after the addition of house fly eggs to each of 4 replicate rearing pans (16 pans total) using a completely randomized design. The SBS was dispersed evenly across the BED surface within each sample pan. Rearing pans were held in the laboratory at a mean ambient temperature of $22^{\circ} \mathrm{C}$, and the same SBS concentrations were reapplied to each pan 3 times/ wk for $23 \mathrm{~d}$.

Experiment 2 was conducted to examine the effect of a single treatment of SBS on the bacteria present in the treated rearing pans as well as on the late-stage or more mature fly larvae present in the BED, perhaps because of the direct effect of acidification. For this experiment, rearing pans containing $1 \mathrm{~L}$ of BED and 3,000 house fly eggs were treated with $0 \mathrm{~g}$ of SBS (CON), $8.9 \mathrm{~g}$ of SBS $/ 0.05 \mathrm{~m}^{2}$ of BED with reapplication of the acidifier 3 times/wk $($ SB3 $\times)$, or $8.9 \mathrm{~g}$ of SBS/0.05 $\mathrm{m}^{2}$ of BED applied only once at $48 \mathrm{~h}$ before the end of the 8-d trial (SB48). The $8.9 \mathrm{~g}$ of SBS application rate was chosen based on the results of the initial experiment above. Following treatment, rearing pans were held in the laboratory at a mean ambient temperature of $24^{\circ} \mathrm{C}$ for $8 \mathrm{~d}$.

The BED moisture level was kept above 35\% throughout both studies by spraying sterile deionized water (approximately $5 \mathrm{~mL}$ ) on the surface of each pan daily. Temperature loggers (HOBO H8 Pro Series, 2-channels, Onset Computer Corp., Bourne, MA) were used continuously to monitor ambient room temperature. The $\mathrm{pH}$ in each pan was measured 3 times/wk by inserting a $\mathrm{pH}$ probe (Accumet, model AR15, Fisher Scientific, Pittsburgh, PA) into the BED at 5 sampling 
points within each pan (located in each quadrant and the center of the pan). At the end of each experimental period, the BED in each pan was first spread on a flat surface and visible house fly larvae and fly pupae were removed by forceps. All BED was then washed through a fine mesh sieve $(0.2 \mathrm{~m} \times 0.2 \mathrm{~m})$ under a slow and gentle stream of water to wash away manure solids and expose any remaining larvae. Larvae were counted as alive or dead (fly pupae were counted as live fly larvae) and preserved in $70 \%$ ethanol.

In experiment 2 , the concentration of aerobic bacteria in the BED was determined for all rearing pans at the end of the 8-d experiment. For each treatment, 0.2-g subsamples of BED from 5 locations within each pan were combined (1.0 g of sample per pan; $4.0 \mathrm{~g}$ of sample per treatment), placed into a $10-\mathrm{mL}$ falcon tube by treatment, cooled to $4^{\circ} \mathrm{C}$, and analyzed within $24 \mathrm{~h}$. Aerobic bacteria were quantified following serial dilution of each sample into PBS, with each diluent vortex agitated for $2 \mathrm{~min}$ before the next dilution. For each dilution, $100 \mu \mathrm{L}$ of the diluent was plated onto brain heart infusion agar plates (Difco, Detroit, MI) and incubated at $37^{\circ} \mathrm{C}$ for $2 \mathrm{~d}$ under normal atmospheric conditions. Bacterial colonies were counted for dilutions resulting in 30 to 300 colonies per plate, and the number of bacteria in the original sample was calculated by multiplying the number of colonies observed on the plate by the reciprocal of the dilution factor.

\section{Statistical Analysis}

The number of live larvae in each pan at the end of each experiment was ranked using PROC RANK and analyzed using PROC MIXED in SAS (SAS Institute, 1999), with differences between mean treatment values examined using least squares means. Adjusted means and standard errors were obtained from the PROC MEANS (treating replication as random) output on the original data. For all analyses, a $P$-value of 0.05 was used to determine significance.

Acidity levels $(\mathrm{pH})$ were averaged by day and treatment, with values placed in rank order for analysis by a repeated measures model using PROC MIXED procedures in SAS to examine differences by day and treatment. The least squares means from these analyses were used to determine differences across treatments. Adjusted means and standard errors were obtained using PROC MEANS on the ranks.

Bacterial concentrations were analyzed using ANOVA, with treatment and day as main effects. The least squares means of averaged bacterial plate counts from PROC GLM in SAS were used to determine differences across treatments. Adjusted means and standard errors were obtained using the PROC MEANS output for bacteria concentrations. A Mantel-Haenszel test was conducted to look at statistical trends over time.

\section{RESULTS}

\section{Experiment 1}

Mean $\mathrm{pH}$ in rearing pans (Figure 1) was inversely related to SBS application rate, with $\mathrm{pH}$ being highest in the CON pans and lowest in the HIGH pans $(P$ $<0.001)$. The mean $\mathrm{pH}$ over all $23 \mathrm{~d}$ was $8.57,1.38$, 1.05, and 0.82 for CON, LOW, MED, and HIGH pans, respectively. The $\mathrm{pH}$ also decreased significantly over time with repeated applications of SBS $(P=0.002)$. The mean number of surviving house fly larvae was greater in untreated CON pans relative to all other SBS treatments $(P<0.001$; Figure 2$)$. The LOW SBS treatment resulted in greater larval survival than the more concentrated (MED and HIGH) SBS treatments $(P<0.05)$, with the latter 2 treatments being similar to each other. Overall, the number of surviving larvae was reduced by 87,99 , and $100 \%$ in the LOW, MED, and HIGH SBS treatments, respectively, as compared with the CON treatment. The number of dead house fly larvae recovered from the BED was similar across treatments.

\section{Experiment 2}

Mean daily $\mathrm{pH}$ differed across treatments $(P<0.001)$, with $\mathrm{pH}$ being similar for the CON and SB48 treatments on $\mathrm{d} 6$, when a single SBS application was made to the SB48 pans, after which the $\mathrm{pH}$ for these treatments differed $(P<0.01$; Figure 3$)$. The mean $\mathrm{pH}$ for the SB3 $\times$ treatment differed significantly $(P<0.001)$ from the CON and SB48 treatments for all days except d 6, when it was not different from the SB48 treatment. The mean number of surviving house fly larvae was similar in the CON and SB48 treatment pans $(P>$ 0.05 ), but the number of surviving larvae was reduced by $90 \%$ in SB3 $\times$ pans $(P<0.01)$ compared with CON pans (Figure 4). The number of dead house fly larvae recovered from the BED was similar across treatments, indicating no significant mortality of late-stage larvae following the application of SBS to the SB48 treatment on d 6. Bacterial plate counts differed significantly by treatment $(P<0.01$; Table 1$)$ and time $(P<0.001)$, with the SB3 $\times$ mean bacterial plate count significantly reduced relative to the $\mathrm{CON}$ and $\mathrm{SB} 48$ bacterial plate counts $(P<0.01)$, which did not differ from each other $(P>0.05)$.

\section{DISCUSSION}

The application of SBS to calf bedding material was shown to reduce $\mathrm{pH}$, bacterial concentration, and larval 


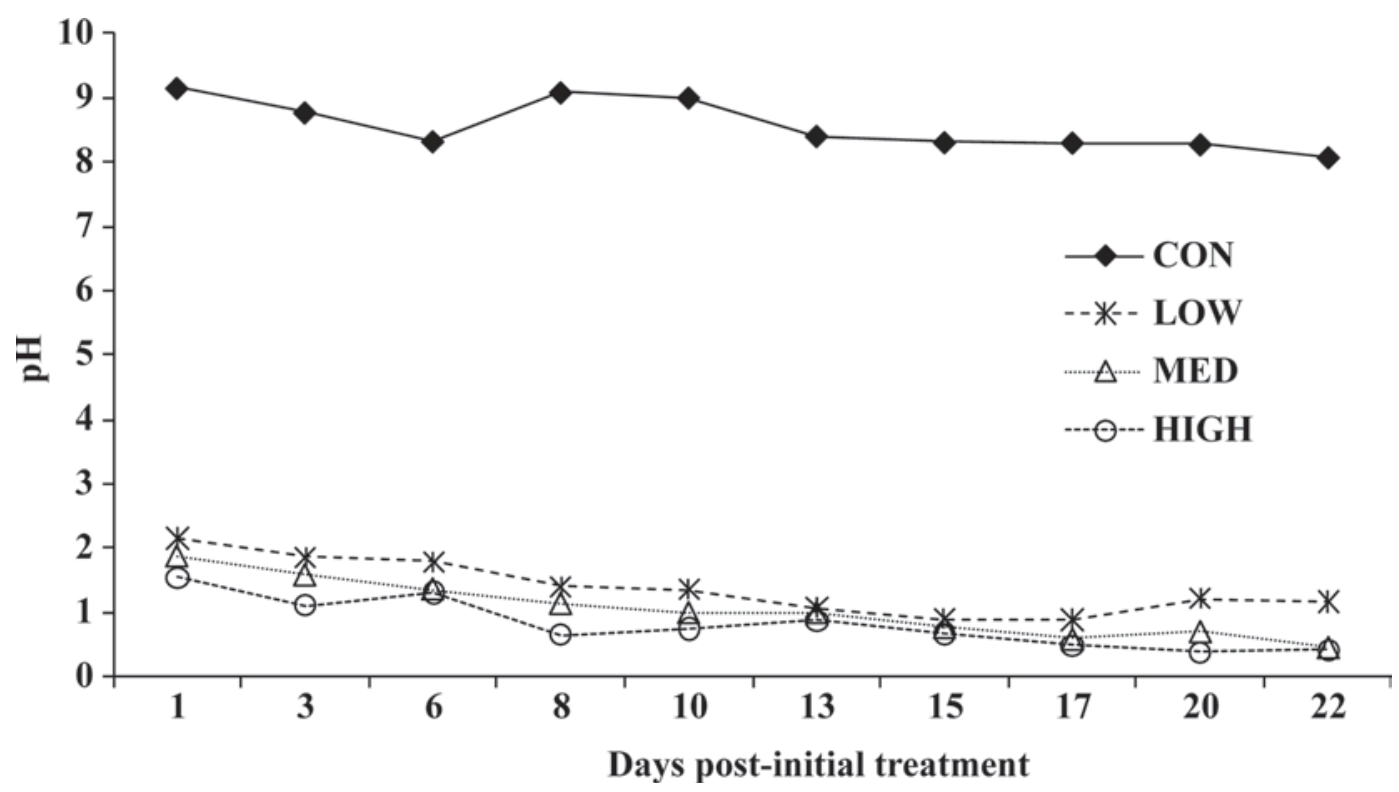

Figure 1. Least squares means of $\mathrm{pH}$ for calf bedding media (BED) treated 3 times/wk with varying levels of acidifying sodium bisulfate (SBS; $\mathrm{n}=4 ; P<0.001$ ). Treatment concentrations were $0,8.9,17.7$, and $26.5 \mathrm{~g}$ of SBS $/ 0.05 \mathrm{~m}^{2}$ of BED surface area (CON, LOW, MED, and HIGH, respectively).

house fly survival. However, larvae survival was not affected by a short-term reduction in $\mathrm{pH}$, indicating that simple acidification was not responsible for the reduction in house fly survival. It appears that BED acidification following the application of SBS directly affects bacterial survival and growth, which indirectly affects the survival of larvae in the treated BED because of the loss of their necessary bacterial food source (Schmidtmann and Martin, 1992; Lysyk et al., 1999).

Previously reported cattle and calf slurry $\mathrm{pH}$ levels range from 7.3 to 8.3 (Weil and Bernard, 1977; Lefcourt and Meisinger, 2001; Sun et al., 2008), which is similar to the $\mathrm{pH}$ of 8 to 9 observed in the $\mathrm{CON}$ pans

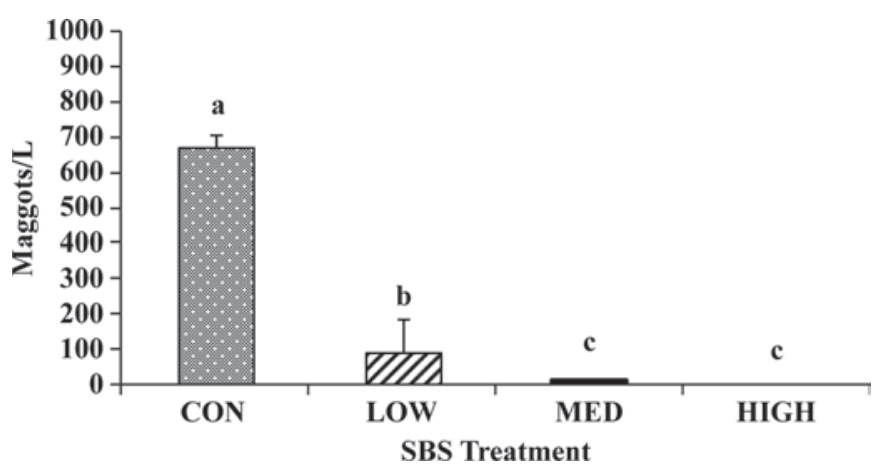

Figure 2. Least squares means ( $\pm \mathrm{SE}$ ) of surviving house fly larvae in calf bedding material (BED) treated 3 times/wk with varying levels of acidifying sodium bisulfate (SBS; $\mathrm{n}=4$ ). Treatment concentrations were $0,8.9,17.7$, and $26.5 \mathrm{~g}$ of SBS $/ 0.05 \mathrm{~m}^{2}$ of BED surface area (CON, LOW, MED, and HIGH, respectively). Means with different letters differ significantly $(P<0.001)$. in this study. The reduction in $\mathrm{pH}$ for SBS-treated pans in this study, 76 to $90 \%$ reduction relative to the CON pans, was also similar to $\mathrm{pH}$ reductions achieved in other studies using SBS for substrate acidification (Pope and Cherry, 2000; Line, 2002; Sun et al., 2008). Substrate acidification with SBS has also been associated with decreased emissions from manure and litter, both of which are common in livestock facilities. Sun et al. (2008) reported decreases in ammonia and alcohol (methanol and ethanol) emissions following SBS application to dairy slurry, whereas Ullman et al. (2004) reported decreased ammonia emissions following SBS

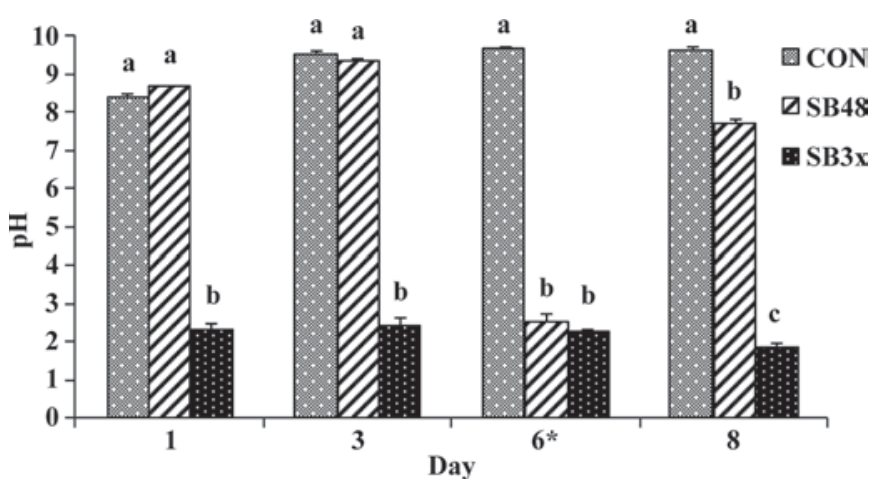

Figure 3. Least squares means $( \pm \mathrm{SE})$ of $\mathrm{pH}$ for calf bedding media (BED) treated with varying levels of acidifying sodium bisulfate (SBS; $\mathrm{n}=4): \mathrm{CON}=0 \mathrm{~g}$ of SBS; SB3 $\times=8.9 \mathrm{~g}$ of SBS $/ 0.05 \mathrm{~m}^{2}$ of BED surface area with reapplication 3 times/wk; SB48 $=8.9 \mathrm{~g}$ of SBS $/ 0.05 \mathrm{~m}^{2}$ of BED surface area during last $48 \mathrm{~h}$ of the trial. Means with different letters differ significantly $(P<0.001)$. Asterisk indicates that $8.9 \mathrm{~g}$ of $\mathrm{SBS} / 0.05 \mathrm{~m}^{2}$ of BED surface area was applied to SB48 pans. 
Table 1. Least squares means and standard errors of aerobic bacteria plate counts $(\mathrm{cfu} / \mathrm{g})$ by sodium bisulfate (SBS) treatment applied to calf bedding

\begin{tabular}{lcc}
\hline SBS treatment $^{1}$ & ${\text { Aerobic bacterial plate count }(\mathrm{cfu} / \mathrm{g})^{2}}^{2}$ & SEM \\
\hline CON & $10.6 \mathrm{E}+09^{\mathrm{a}}$ & $3.60 \mathrm{E}+09$ \\
SB3 $\times$ & $3.4 \mathrm{E}+09^{\mathrm{b}}$ & $2.10 \mathrm{E}+09$ \\
SB48 & $11.5 \mathrm{E}+09^{\mathrm{a}}$ & $4.50 \mathrm{E}+09$ \\
\hline
\end{tabular}

${ }^{\mathrm{a}, \mathrm{b}}$ Means within a column with different superscript letters differ $(P$ $<0.01)$.

${ }^{1} \mathrm{CON}=0 \mathrm{~g}$ of SBS; SB3 $\times=8.9 \mathrm{~g}$ of SBS $/ 0.05 \mathrm{~m}^{2}$ of bedding material (BED) surface area with reapplication $3 \times /$ wk; SB48 $=8.9 \mathrm{~g}$ of SBS $/ 0.05 \mathrm{~m}^{2}$ of BED surface area during last $48 \mathrm{~h}$ of the trial.

${ }^{2}$ Mean bacterial plate counts for pans containing calf BED and 3,000 house fly eggs $(n=4)$.

application to poultry litter. Acidification of manure or animal bedding may also help to reduce the transmission of animal pathogens, as was noted by the reduction of Campylobacter infection in broiler flocks following SBS treatment of their poultry litter (Line, 2002). Similarly, a reduction of pathogenic bacteria $(E$. coli and Salmonella) in commercial broiler farms following SBS application (Pope and Cherry, 2000) may prevent these pathogens from entering the processing plant on live broilers.

Previously, it was demonstrated that adult fly populations could be reduced by the application of SBS to equine bedding in horse facilities (Sweeney et al., 2000). However, the mechanism of this reduction in adult fly numbers was unclear. From the results of the present study, it can be extrapolated that SBS application to equine bedding would have resulted in a reduction in bacterial concentrations and therefore a reduction in the survival of immature flies requiring these bacteria as a food source.

In this laboratory study, acidification of calf BED with SBS resulted in reduced production of house flies. It remains to be shown whether acidification of calf

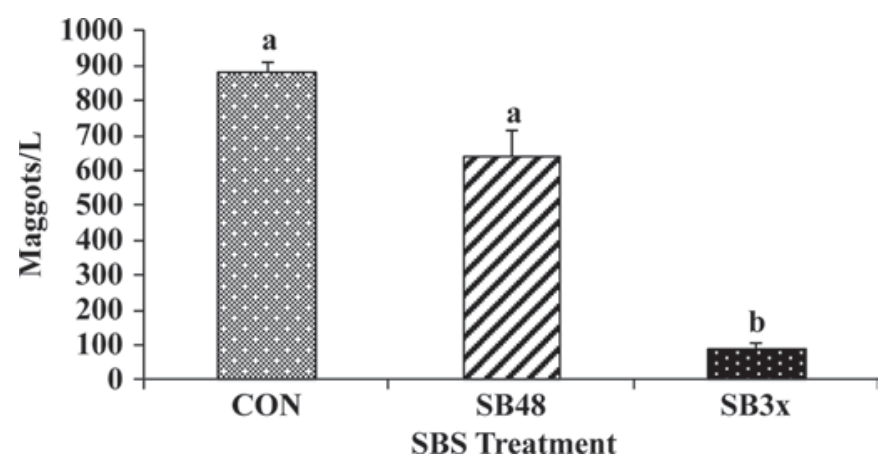

Figure 4. Least squares means ( $\pm \mathrm{SE}$ ) of surviving house fly larvae in calf bedding material (BED) treated with varying levels of acidifying sodium bisulfate (SBS; $\mathrm{n}=4$ ): $\mathrm{CON}=0 \mathrm{~g}$ of SBS; SB3 $\times=8.9 \mathrm{~g}$ of SBS/0.05 $\mathrm{m}^{2}$ of BED surface area with reapplication 3 times/wk; $\mathrm{SB} 48=8.9 \mathrm{~g}$ of SBS $/ 0.05 \mathrm{~m}^{2}$ of BED surface area during last $48 \mathrm{~h}$ of the trial. Means with different letters differ significantly $(P<0.001)$.
BED using SBS under natural field conditions would provide a similar reduction in the number of immature house flies. Under natural conditions, continued defecation, feed spillage, and general disturbance of the bedding by calves in treated pens might reduce the level of house fly control achieved in these laboratory studies. Although a reduction in immature house fly survival in calf BED (a common fly production source in facilities with calves) would be expected to reduce adult fly populations at the facility, this would need to be confirmed by a large-scale field trial.

Future research also needs to include studies on the effects of the SBS acidifier on calf well-being (i.e., skin lesions, respiratory tract, gastrointestinal tract, and so on) and the ability of SBS to work effectively in other locations of a dairy commonly associated with larvae (manure storage, drylot corrals, freestall barns, and so on). Studies also need to include the financial feasibility of SBS. The application rates used in the present experiments translate into field application rates of 1 , 2 , and $3 \mathrm{lbs}(0,0.45,0.91$, and $1.36 \mathrm{~kg}$, respectively) of $\mathrm{SBS} / 5.4 \mathrm{~m}^{2}$ of calf hutch surface area. At $\$ 25 / 50 \mathrm{lbs}$ $(22.7 \mathrm{~kg})$ of SBS, the cost to apply SBS at $1 \mathrm{lb}(0.45 \mathrm{~kg})$ of SBS $/ 5.4 \mathrm{~m}^{2}$ of hutch surface area (for calves housed in hutches for $60 \mathrm{~d}$ ) would be approximately $\$ 12 /$ calf. Finally, it would be of great benefit to determine whether the same results can be achieved for stable fly larvae. Stable flies are considered to be another major pest impeding cattle welfare (Campbell et al., 1977; Berry et al., 1983; Schwinghammer et al., 1986). Both house and stable flies (McPheron and Broce, 1996) prefer and survive under high $\mathrm{pH}$ conditions, and acidification of calf bedding might be an equally effective mitigation tool for both species.

\section{CONCLUSIONS}

The application of SBS to calf bedding material indirectly reduced house fly larval survival by directly affecting bacterial survival and growth. Acidification as a mode of fly management can be beneficial to many areas of a dairy facility, especially for areas housing newborn calves. By reducing larval density and bacterial populations, calf housing areas can potentially serve as less attractive sites to adult flies for laying eggs (oviposition). Reducing the pest load on newborn calves through acidification of bedding may be one solution that would lessen the severity of management stresses and transmission of pathogens.

\section{ACKNOWLEDGMENTS}

We thank Jones-Hamilton Co. (Walbridge, $\mathrm{OH}$ ) for providing the SBS product used in these studies. We 
also thank the graduate and undergraduate students in the Department of Animal Science at University of California, Davis (Veronica Arteaga, Rona Silva, Kim Stackhouse, Kristin Renkei, Michael Tobias, Joshua Ettlin, Johnny Garcia, Sara Place, Qian Wang, Casey Weissburg, Michelle Sanborn, Erin Russell, Cecilia Chen, Jacob Murphy, and Conor Hoff) for their assistance throughout the studies, Diane Zhang at the University of California, Riverside Department of Entomology for providing house fly eggs, and Inna Ovchinnikova at the USDA ARS (Albany, CA) for her help with the bacterial plate counts.

\section{REFERENCES}

Ahmad, A., T. G. Nagaraja, and L. Zurek. 2007. Transmission of Escherichia coli O157:H7 to cattle by house flies. Prev. Vet. Med. 80:74-81.

Anderson, J. R. 1966. Recent developments in the control of some arthropods of public health and veterinary importance. Muscoid Flies. Bull. Ent. Soc. Am. 12:342-346.

Berry, I. L., D. A. Stage, and J. B. Campbell. 1983. Populations and economic impacts of stable flies on cattle. Trans. ASAE 26:873877.

Campbell, J. B., J. E. Wright, R. Crookshank, and D. C. Clanton. 1977. Effects of stable flies on weight gains and feed efficiency of calves on growing or finishing rations. J. Econ. Entomol. 80:592594

Chang, J. T., and M. Y. Wang. 1958. Nutritional requirements of the common housefly, Musca domestica vicina Macquart. Nature 181:566.

EPA (Environmental Protection Agency). 1993. Prevention, Pesticides, and Toxic Substances-Mineral Acids. EPA 738-R-029. National Service Center for Environmental Publications. Cincinnati, OH.

Gerry, A. C., J. H. Klotz, L. Greenberg, and N. C. Hinkle. 2004. Flies. In Pest Notes. Publication 7457. Agriculture and Natural Resources, University of California, Davis. http://www.ipm. ucdavis.edu/PDF/PESTNOTES/pnflies.pdf Accessed Aug. 11, 2009.

Gerry, A. C., N. G. Peterson, and B. A. Mullens. 2007. Predicting and controlling stable flies on California dairies. Publication 8258. Agriculture and Natural Resources, University of California, Davis. http://anrcatalog.ucdavis.edu/pdf/8258.pdf Accessed Aug. 11, 2009.

Greenberg, B. 1973. Flies and Disease. Vol. 2. Princeton University Press, Princeton, NJ.

Hald, B., H. Sommer, and H. Skovgård. 2007. Use of fly screens to reduce Campylobacter spp. introduction in broiler houses. Emerg. Infect. Dis. 13:1951-1953.

Hansens, E. J., E. S. Evans Jr., and D. B. Shibles. 1968. Tests of bromophos for house fly control in New Jersey. J. Econ. Entomol. 61:833-836.

Lefcourt, A. M., and J. J. Meisinger. 2001. Effect of adding alum or zeolite to dairy slurry on ammonia volatilization and chemical composition. J. Dairy Sci. 84:1814-1821.

Line, J. E. 2002. Campylobacter and Salmonella populations associated with chickens raised on acidified litter. Poult. Sci. 81:1473-1477.

Lysyk, T. J., L. Kalischuk-Tymensen, L. B. Selinger, R. C. Lancaster, L. Wever, and K. J. Cheng. 1999. Rearing stable fly larvae (Diptera: Muscidae) on an egg yolk medium. J. Med. Entomol. 36:382-388.

Mandeville, J. D., B. A. Mullens, and J. A. Meyer. 1988. Rearing and host age suitability of Fannia canicularis (L.) (Diptera: Muscidae) for parasitization by Muscidifurax zaraptor Kogan and Legner (Hymenoptera: Pteromalidae). Can. Entomol. 120:153-159.
McPheron, L. J., and A. B. Broce. 1996. Environmental components of pupariation-site selection by the stable fly (Dipteria: Muscidae). Environ. Entomol. 25:665-671.

Meyer, J. A., and J. J. Petersen. 1983. Characterization and seasonal distribution of breeding sites of stable flies and house flies (Diptera: Muscidae) on eastern Nebraska feedlots and dairies. J. Econ. Entomol. 76:103-108.

Moriya, K., T. Fujibayashi, T. Yoshihara, A. Matsuda, N. Sumi, N. Umezaki, H. Kurahashi, N. Agui, A. Wada, and H. Watanabe. 1999. Verotoxin-producing Escherichia coli O157:H7 carried by the housefly in Japan. Med. Vet. Entomol. 13:214-216.

Perotti, M. A., T. J. Lysyk, L. D. Kalischuk-Tymensen, L. J. Yanke, and L. B. Selinger. 2001. Growth and survival of immature Haematobia irritans (Diptera: Muscidae) is influenced by bacteria isolated from cattle manure and conspecific larvae. J. Med. Entomol. 38:180-187.

Pickens, L. G., N. O. Morgan, J. G. Hartsock, and J. W. Smith. 1967. Dispersal patterns and populations of the house fly affected by sanitation and weather in rural Maryland. J. Econ. Entomol. 60:1250-1255

Pope, M. J., and T. E. Cherry. 2000. An evaluation of the presence of pathogens on broilers raised on poultry litter treatment-treated litter. Poult. Sci. 79:1351-1355.

Romero, A., A. Broce, and L. Zurek. 2006. Role of bacteria in the oviposition behaviour and larval development of stable flies. Med. Vet. Entomol. 20:115-121.

SAS Institute. 1999. SAS. Version 9.1. SAS Institute, Cary, NC.

Schmidtmann, E. T. 1988. Exploitation of bedding in dairy outdoor calf hutches by immature house flies and stable flies (Diptera: Muscidae). J. Med. Entomol. 25:484-488.

Schmidtmann, E. T. 1991. Suppressing immature house and stable flies in outdoor calf hutches with sand, gravel, and sawdust bedding. J. Dairy Sci. 74:3956-3960.

Schmidtmann, E. T., and P. A. W. Martin. 1992. Relationship between selected bacteria and the growth of immature house flies, Musca domestica, in an axenic test system. J. Med. Entomol. 29:232235.

Schmidtmann, E. T., R. W. Miller, and R. Muller. 1989. Effect of experimental bedding treatments on the density of immature Musca domestica and Stomoxys calcitrans (Diptera: Muscidae) in outdoor calf hutches. J. Econ. Entomol. 82:1134-1139.

Schwinghammer, K. A., F. W. Knapp, J. A. Boling, and K. K. Schillo. 1986. Physiological and nutritional response of beef steers to infestations of the stable fly (Diptera: Muscidae). J. Econ. Entomol. 79:1294-1298

Sun, H., Y. Pan, Y. Zhao, W. A. Jackson, L. M. Nuckles, I. L. Malkina, V. E. Arteaga, and F. M. Mitloehner. 2008. Effects of sodium bisulfate on alcohol, amine, and ammonia emissions from dairy slurry. J. Environ. Qual. 37:608-614.

Sweeney, C. R., T. Scanlon, G. E. Russell, G. Smith, and R. C. Boston. 2000. Effect of daily floor treatment with sodium bisulfate on the fly population of horse stalls. Am. J. Vet. Res. 61:910-913.

Terzich, M., C. Quarles, M. A. Goodwin, and J. Brown. 1998a. Effect of Poultry Litter Treatment (PLT) on the development of respiratory tract lesions in broilers. Avian Pathol. 27:566-569.

Terzich, M., C. Quarles, M. A. Goodwin, and J. Brown. 1998b. Effect of Poultry Litter Treatment (PLT) on death due to ascites in broilers. Avian Dis. 42:385-387.

Thomas, G. D. 1993. Rural flies in the urban environment. N. Centra Regional Res. Pub. No. 335, University of Nebraska, Lincoln.

Thomsen, M., and O. Hammer. 1936. The breeding media of some common flies. Bull. Entomol. Res. 27:559-587.

Ullman, J. L., S. Mukhtar, R. E. Lacey, and J. B. Carey. 2004. A review of literature concerning odors, ammonia, and dust from broiler production facilities: 4 . Remedial management practices. J. Appl. Poult. Res. 13:521-531.

Watson, D. W., P. A. W. Martin, and E. T. Schmidtmann. 1993. Egg yolk and bacteria growth medium for Musca domestica (Diptera: Muscidae). J. Med. Entomol. 30:820-823.

Weil, A., and C. R. Bernard. 1977. Veal-calf manure deodorization by surface aeration. Agric. Environ. 3:197-206. 